\title{
Building Effective School Culture Through Visionary Leadership
}

\author{
Hilal Mahmud \\ Institut Agama Islam Negeri Palopo \\ Palopo, Indonesia
}

\begin{abstract}
The aim of this study is first to find out the profile of visionary leadership. Secondly, the mechanism adopted to implement a shared vision, and finally the strategies in building an effective school culture in SMA Negeri 2 Palopo. This research includes field research that is verified qualitatively. Data collection methods were interviews, observation, and documentation. The results of this study indicate that the profile visionary leadership of principal includes having a clear vision and mission, strategic understanding environment, and character of visionary leadership. The mechanism adopted to implement a shared vision are analyzing the strategic environment and developing programs in strategic planning and operational planning. In addition, the strategy adopted in building an effective school culture is establishing the commitment of an effective culture, providing a thorough understanding of vision, mission and objectives of the school, determining clear policy direction, and emphasizing the importance of creativity and innovation.
\end{abstract}

Keywords—culture; effective schools; visionary leadership

\section{INTRODUCTION}

A teacher needs encouragement, and a conducive atmosphere to realizing quality learning requires school leadership that can develop any teacher to become a selfleader. Self-leader is leadership through the expansion strategy that is focused on behaviour, thinking and feeling used to influence oneself to be responsible for overcoming the threats. Moreover, the super leader is a leader who uses a model of commitment and empowering lead.

The self-leader teacher is the teacher who has the mindset, behaviour and responsibility of overcoming the threats imposed upon him, initiative, creative, innovative, and able to lead himself. A school principal who can design, establish a system, affecting and shaping the teacher becomes a selfleader is a super leader [1]. Developing every teacher be effective self-leader is an exciting challenge for the principal to lead and motivate the teachers to transfer of responsibility assigned to them at the same time lead themselves in carrying out responsibility.

Super leader as principal's power can be demonstrated in its ability to arise commitment of the teachers they lead to vision. The principal as a super leader has a vision and are committed to realizing his vision can also be called visionary leadership. The visionary leadership of principal is a manifestation of consciousness and the belief that they are the best people as stated in QS. Ali 'Imran/3: 110.

The effective school culture requires not only professional teachers but also the visionary leadership of principal to make room for the growth and development of creativity and innovation of teachers in anticipating the rapid change. Study results of Adam et al. in 1980 showed that the interests and achievements of teachers have only appeared in the first three years of teaching and slumped after some time has passed [2]. This study indicates the need for the principal's assistance in building an effective school culture. The school principal should apply the visionary leadership that can influence the climate and school culture that encourages the improvement of performance of teachers in performing their professional duties.

In this research Sekolah Menengah Atas (SMA) Negeri 2 Palopo was selected as an object based on the fact that it has tried to build an effective school culture through the visionary leadership of the principal.

\section{VISIONARY LEADERSHIP PROFILE}

SMA Negeri 2 Palopo, under the leadership of the principal, has a clear vision and mission formulated together with the school community and disseminated to all citizens and school committees. Vision and mission are realized through programs and activities both medium-term organized into strategic planning (five years) and short-term arranged in the form of operational planning (one year). Head of SMA Negeri 2 Palopo as visionary leaders has an understanding of the strategic environment. School programs are established through SWOT analysis (Strengths, Weaknesses, Opportunities, and Threats) of being a major consideration in preparing a good program in Strategic Planning and the Operational Planning. In building a future school, SMA Negeri 2 Palopo makes use of the strength and opportunity for change towards a better future. In fact, the school seeks to existing threats can be turned into an opportunity to realize the vision and mission.

The need for encouragement and enthusiasm to achieve quality learning requires school leadership that is a super leader [3]. Mulyadi \& Rivai argues that super leader is a leader who can lead others to lead themselves [1]. The Super leader encourages others to take responsibility rather than giving orders. The Super leader focuses on the empowerment 
strategy through improving skills, knowledge, and belief in the abilities and potential of teachers' led.

The principal as a visionary leader has a capacity of powering the energy and commitment of the educators and staff to carry out their jobs as a call of duty and dares to neglect their personal interests for the sake of duties and responsibilities. Daft asserts that charismatic leaders are experts in the art of visionary leadership that can inspire and motivate people to do something beyond their abilities, even if faced with obstacles and personal sacrifice [3].

Inspiring and motivating are challenges for a school principal. To encourage educators and staff motivated to develop their performance, principal needs to consider some theories about motivation [4]. We have Maslow's hierarchy of needs theory that was modified and simplified by Clayton Alderfer theory ERG (ERG theory). Frederick Herzberg suggested that the motivation is influenced by two factors, namely hygiene and motivator factors [3]. Edwin Locke and Gary Latham with goal-setting theory suggested that the motivation and achievement can be enhanced by formulating specific targets and challenging, then helping people achieve the target by providing feedback promptly.

\section{MECHANISMS FOR IMPLEMENTING SHARED VISION}

The mechanisms for implementing a shared vision in SMA Negeri 2 Palopo started with the establishment of the mission, goals, and objectives based on the vision implemented in the form of program plans. The Drafting of Strategic Plan is based on the vision and mission made to meet an effort for improving quality in schools. The program is set to consider the strengths, weaknesses (internal environment), opportunities and threats (the external environment). To ensure the implementation of the program according to plan, monitor and evaluate the implementation of the program is done.

Still, there is a fundamental need for educators and staff to improve their professionalism have not been accommodated in the school program. For example, educators were just given the opportunity to attend seminars, workshops and the like. In consideration of cost, time, and the lack of such activities carried out at the district level, so they do not use the opportunity provided. Moreover, in general, they are given the task of teaching hours to exceed the amount of the obligation.

Another thing that needs to be considered by the principal to build effective schools is reducing the number of tasks that must be done by educators. At least, educators teaching in the classroom pursued in parallel, so they are spared from some administrative tasks that burden them. In addition, a principal can perform a significant way to meet the needs of the motivation of educators by empowerment. For example, workshops and activities of performance development should be transferred to them through a group of teachers alike. They are given authority and power to design their performance development according to their needs as their perception. Research shows that increasing the power of employees can increase the motivation to get succeed [5]. Principal can make them reach this achievement and performance to match the powers given to him by giving four things, namely: (a) having access to information of any good school aspects; (b) acquiring knowledge and skills based on their needs; (c) having authority to influence working procedures and organizational performance through self-directed work teams; and (d) obtaining performance-based awards [6].

\section{Strategy In Building A Culture Of EFFective SCHOOL}

An effective school culture that has become common practice focused on management, implementation of academic and non-academic activities in SMA Negeri 2 Palopo. Effective culture built related to school management, including (a) involving the participation of parents and the organization of the School Committee; (b) receiving input and advice from parents and communities; (c) academic supervision is not only implemented by the principal and school superintendent, but also senior teachers appointed by the principal; (d) Parents and the public informed about the progress of the school.

Effective school culture in the implementation of academic activities, i.e.: (1) maximizing learning time; (2) having an awareness of academic success; and (3) having collaborative planning. Meanwhile, effective school culture in the implementation of non-academic activities, i.e.: (a) providing a variety of extracurricular activities; (b) the school committee is always taken part in any formulation of school program; (c) receiving feedback from the parents of students and community leaders; (d) informing the parents of students about the development of students; (e) opening space for participation of learners; (f), students are given an understanding of the school rules and regulations; $(\mathrm{g})$ whole school community have the same responsibility. Some cultures developed on SMA Negeri 2 Palopo is in line with some of the characteristics and indicators of effective schools proposed by Mortimore [2].

The strategy adopted by the Head of SMA Negeri 2 Palopo in building an effective school culture are: (1) establishing commitment of effective culture; (2) providing a thorough understanding of the vision, mission and objectives of the school; (3) defining a clear policy direction; (4) stressing the importance of creativity and innovation. Building commitment is one way to build trust. A leader can select four different types of commitments, namely: (1) commitment to a course of action; (2) commitment to an ambitious goal; (3) commitment to stretch relationship; (4) commitment to an operating philosophy [7]. All leaders will face difficult situations in choosing and define commitments. The problem is how to determine the right type of commitment [8]. To help to overcome the problem, let's have a look at Conner six-point guidance in building commitment [7].

\section{CONCLUSION}

Based on the results of research and discussion above, the researcher can conclude that: (1) Profile visionary leadership in SMA Negeri 2 Palopo includes having a clear vision and mission, understanding the strategic environment, and having the character of visionary leadership; (2) The mechanism to implement a shared vision in SMA Negeri 2 Palopo are 
analyzing the strategic environment, and developing a program in strategic planning and operational planning; and (3) The strategy in building an effective school culture at SMA Negeri 2 Palopo are establishing commitment of an effective culture, providing a thorough understanding of vision, mission and objectives of the school, determining clear policy direction, and emphasizing importance of creativity and innovation.

The practical implication is that the visionary leadership of the principal required professional management and effective tough school leadership.

\section{REFERENCES}

[1] D. Mulyadi and V. Rivai, 'Kepemimpinan dan Perilaku organisasi', Jakarta PT. Raja Graf. Persa, 2012.

[2] Supardi, Kinerja Guru. Jakarta: Rajawali Pers, 2013.

[3] R. L. Daft, 'Era Baru Manajemen', Jakarta: Salemba Empat, 2010.

[4] H. Usman, 'Manajemen: Teori, Praktik dan Riset Pendidikan', 2014.

[5] J. A. Conger and R. N. Kanungo, 'The empowerment process: Integrating theory and practice', Acad. Manag. Rev., vol. 13, no. 3, pp. 471-482, 1988.

[6] D. BOWEN, 'E. and EDWARD E', LAWLER. Empower. ser vice Work. Sloan Manag. Re view, vol. 33, no. 3, pp. 31-39, 1992.

[7] Wibowo, Manajemen Kerja, Ketiga. Jakarta: PT. Raja Grafindo Persada, 2011.

[8] I. A. B. Putra, '60 Management Gems: Applying Management Wisdom in Life', 2010. 